\title{
The Ongoing Dilemma of Professionalism
}

\author{
ROB CORSER \\ University of Washington
}

\begin{abstract}
While architecture and design can be considered to fall under the umbrella of the arts, key differences make architectural practice distinct from arts based community engagement, and in some ways problematic. This paper focuses on traditions of professional organization and oversight that both raise expectations for civic responsibility and simultaneously present institutional challenges to deeper engagement. While most concepts of professionalism pay lip service to the public good, I will argue for the importance of maintaining and expanding the values of community engagement that wax and wane in architecture and design education. I will characterize an approach of Design Engagement as contrasted with Design Assistance and offer some principles that might foster more truly collaborative and publicly-engaged design practices.
\end{abstract}

\section{PROFESSIONALISM AND THE PUBLIC GOOD}

As a profession, architecture is distinct from other arts because it defines itself in an exclusionary manner. Like Law, Medicine and other professions, strict norms of education, testing, professional development and conduct mark it's distinction. An artist, writer, or filmmaker may choose to produce work of a very personal nature, or they may choose to work in a very public manner, collaborating with others in order to express ideas important to the community. In either case, this decision remains the choice of the individual artist, and is generally not subject to professional oversight.

Architecture however, occupies an odd middle ground. What happens when the desires of an architect or their client and those of the community do not align? Who does the architect serve most? While these questions reveal the some of the moral complexity underlying all professions, this essay will focus specifically on the implications of advocating for the public good in the practice of architecture and in design education.

While the general public might think of architects in general as being socially progressive, the reality is uncertain. Even this vague impression has been in doubt as recently as the AIA's semi-congratulatory statement upon the election of Donald Trump and its almost immediate retraction in November 2016. When Whitney Young Jr., the civil rights activist and head of the Urban League from 1961 to 1971, addressed the 1968 AIA national convention, he castigated architects for their lack of social engagement, saying, "You are not a profession that has distinguished itself by your social and civic contributions to the cause of civil rights. You are most distinguished by your thunderous silence and your complete irrelevance." ${ }^{11}$ Responding to Young's provocation, the profession began, albeit slowly, to re-focus on its commitments to community and society, most notably through aspects of architectural education. But the current situation in architectural practice seems to be only marginally better than fifty years ago. Why is this the case? What more can be done in design education to insure that future generations don't loose focus on architecture's commitment to social relevance? And how might design education better lead the way in developing more socially-engaged design practices as models for the profession?

\section{PROFESSIONS AS CLOSED SOCIETIES THAT SCHOOLS MAY BE A MEANS OF OPENING}

According to the Oxford English Dictionary, the word 'profession' has several senses that shed light on its seemingly contradictory nature, at least in regard to social priorities. Some highlights of the OED definitions include:

The declaration, promise, or vow made by a person entering a religious order; (hence) the action of entering such an order; the fact or occasion of being professed in a religious order.

And:

An occupation in which a professed knowledge of some subject, field, or science is applied; a vocation or career, especially one that involves prolonged training and a formal qualification.

Finally:

More widely: any occupation by which a person regularly earns a living. ${ }^{2}$

Thus, the terms 'profession' or 'professional' combine a sense of a unique group's commitment to a set of shared values with a sense of this group's exclusivity by virtue of its members' sworn allegiance to a creed and the education and training required for membership in that group.

Added to this sense of exclusivity is the fact that a professional occupation is often practiced for monetary compensation. This sort of quasi-monastic group of specialists for hire 
embodies an internal contradiction. In legal terms, the regulation of the architectural profession stems from concerns about public safety and legal codes of business regulation. While the state agencies that oversee the licensing of architects are concerned mainly that they 'do no harm,' the profession itself simultaneously exhibits a call to higher standards and a desire to prop up the profession's reputation. While perhaps dedicating itself to an abstract notion of the 'public good,' professions consciously separate themselves as somehow apart from, and even elevated above, the society whose best interests it serves and is often sworn to uphold.

\section{PROFESSIONAL REQUIREMENTS AND EDUCATION}

Among other functions, the American Institute of Architects (AIA) maintains the profession's "Code of Ethics \& Professional Conduct," which is regularly updated. The most recent version from February 2017 is a highly streamlined 4 pages that consists of Canons (broad principles of conduct,) Ethical Standards and highly specific Rules of Conduct. Canon II, "Obligations to the Public" addresses the public good stating simply that: "Members should embrace the spirit and letter of the law governing their professional affairs and should promote and serve the public interest in their personal and professional activities." 3 Two relevant Ethical Standards give more specificity:

\section{E.S. 2.2 Public Interest Services:}

Members should render public interest professional services, including pro bono services, and encourage their employees to render such services. Pro bono services are those rendered without expecting compensation, including those rendered for indigent persons, after disasters, or in other emergencies.

\section{E.S. 2.3 Civic Responsibility:}

Civic Responsibility: Members should be involved in civic activities as citizens and professionals, and should strive to improve public appreciation and understanding of architecture and the functions and responsibilities of architects. $^{4}$

But the remainder of the code is silent about the proactive actions architects might take in support of the public good. It is noteworthy that Ethical Standards 2.2 and 2.3 were only inserted into the Code of Ethics in 2007. At the time there was a parallel effort to draft guidelines for pro bono services. This document stated that: "To date, the AIA has never had guidelines governing its members' activities as they relate to pro bono services." 5

Entitled, "Institute Guidelines to Assist AIA Members, Firms and Components in Undertaking Pro Bono Service Activities," it begins with an introduction that describes its purpose:
The American Institute of Architects encourages all of its members, their firms, and state and local components to engage in providing pro bono services as part of their contributions to the highest aspirations of the architecture profession and the Institute in service to society. Through participation in whatever format they may choose, every member of the AIA can support and further the values of the Institute in terms of its advocacy for sustainable design and practices, diversity, and elevation of the stature of the profession of architecture in the eyes of the public. ${ }^{6}$

The last phrase is quite telling, since it appears here that one of the major concerns spurring the AIA to action is its public image.

The document goes on to describe, at length, the contribution of architectural education to the profession's on-again, off-again history of civic engagement:

Starting in the 1960s, both university-based and community-based design studios were formed to respond to the pressing need for professional expertise by many innercity neighborhood groups and coalitions for planning and design services. During this same time, faculty and students in the academy were questioning the relevancy of the traditional studio model when the "real learning" was taking place in the streets. By 1980 many schools had unfortunately totally dropped or reduced this approach to design education. However, the Boyer Report, authored by Drs. Ernest Boyer and Lee Mitgang in 1996, included a chapter titled "Service to the Nation," which revived the concept of service-learning/community outreach as an integral component of a viable architecture curriculum. In the dozen years since the report was first issued, the National Architectural Accrediting Board (NAAB) has developed, refined and applied various criteria relating to community-based, service learning in their accrediting process. $^{7}$

The NAAB, founded in 1940 sets criteria for accrediting professional architecture programs and updates them every 5 years. Looking at the changes from 2004 to 2009, and the most recent 2014 update, is quite telling. The final of the five "perspectives" that accredited architecture programs are expected to demonstrate has addressed civic duty in all three of these updates, but in greatly different ways.

The following three highlighted extracts show the gradual backing away from specific guidance concerning public engagement in the NAAB perspectives from 2004 to the latest edition in 2014:

It is striking that in an attempt to clarify requirements, the editing of this perspective has lost all specific mention of the 


\section{Architectural Education and Society}

The program must demonstrate that it equips students with an informed understanding of social and environmental problems and develops their capacity to address these problems with sound architecture and urban design decisions. In the APR (Architecture Program Report), the accredited degree program may cover such issues as how students gain an understanding of architecture as a social art, including the complex processes carried out by the multiple stakeholders who shape built environments; the emphasis given to generating the knowledge that can mitigate social and environmental problems; how students gain an understanding of the ethical implications of decisions involving the built environment; and how a climate of civic engagement is nurtured, including a commitment to professional and public services.

Figure 1: NAAB Perspective, $2004^{8}$

\section{Architectural Education and the Public Good}

That students enrolled in the accredited degree program are prepared: to be active, engaged citizens; to be responsive to the needs of a changing world; to acquire the knowledge needed to address pressing environmental, social, and economic challenges through design, conservation and responsible professional practice; to understand the ethical implications of their decisions; to reconcile differences between the architect's obligation to his/her client and the public; and to nurture a climate of civic engagement, including a commitment to professional and public service and leadership.

Figure 2: NAAB Perspective, $2009^{9}$.

\section{Community and Social Responsibility}

The program must describe its approach to developing graduates who are prepared to be active, engaged citizens able to understand what it means to be professional members of society and to act ethically on that understanding.

Figure 3: NAAB Perspective, $2014^{10}$ "public good" or civic engagement through public service. Rather than move toward more specific emphases, the key document that defines the goals of professional architectural education is moving instead toward increasingly generic descriptions of professional ethics.

This is not a promising development in the struggle to break down the barriers of professional isolation and to make professional architectural practice more relevant to society at large. But what is it about the nature of 'professionalism' in general that makes the inclusion of the 'public interest' so problematic, and why does the NAAB seems to be backing away from specific encouragement of civic engagement while simultaneously most schools are continuing to move forward with greater efforts in addressing the public good?

Today, most professional schools of architecture include at least some sort of community-based learning opportunities in their curricula. This ongoing change is being driven by the interest of students as much as any other factor. According to the 1996 Boyer Report "Building Community: A New Future for Architecture Education and Practice", almost a quarter of students entering architectural education cited "improving the quality of life in their communities" as their top motivation for entering the profession. ${ }^{11}$ Community-engaged educational programs take many forms, but the most commonly found are Community Design Centers (CDCs) and DesignBuild (DB) programs. CDCs are generally outreach initiatives that provide pro bono student generated design services to local communities in need, and projects can vary in scale from small parks and street improvement proposals to larger urban design strategies. Design-Build programs typically focus on physically constructed projects at a wide range of scales like a single affordable home, a community garden, or school play structure, and even larger community buildings. While these projects are often smaller than those addressed by CDCs, they differ more because they move beyond design services to actually fund and construct the projects, in part or in their entirety. It is through these initiatives that architectural education can inspire professional transformation through community-engaged design activities. Despite all of this, it is alarming to sense a lack of official enthusiasm from the NAAB as exhibited in their official statements, and while progress is being made, differing educational approaches to public service are apparent in academia.

\section{DESIGN EDUCATION: RE-DESIGNING THE DESIGN PROCESS ITSELF}

[It is easy to identify existing school-based and even probono professional practices that engage their communities more meaningfully, but changing long-standing attitudes about the role of the architect and adopting new, more collaborative working methods present real challenges. These practices embody several defining characteristics of more deeply engaged design, and the next section of this paper 
proposes principles that might be employed to improve existing approaches, and can re-inform what "professionalism" could mean in the context of social engagement.

\section{TWO MODELS: DESIGN ASSISTANCE VERSUS DESIGN ENGAGEMENT}

As with any collaborative endeavor, community-engaged projects vary greatly in their degree of participatory involvement. In fact, the very terminology of traditional 'design 'services' perpetuates a hierarchy between the design 'professional' and the 'client' to be served. While many academic programs favor the term 'collaborator' or 'community partner,' far too often old biases still prevail. More truly reciprocal collaboration still remains an ideal that must be encouraged at every step of engagement. While professionally trained designers, even as students, bring skills and knowledge to the table that most community members do not possess, many of the most well-intentioned community-based projects fail to adequately solicit or even acknowledge the depth of tacit knowledge that resides in our communities and partners.

\section{DESIGN ASSISTANCE}

Academic programs dedicated to collaborative design, especially design-build projects, face enormous pressures that weigh against the potentially slow pace and unpredictable direction of deeper collaboration. I recently interviewed the director of an arts organization in a small town recovering from a devastating natural disaster. A high profile university design-build program volunteered to build a new home for the organization, and the building, completed in less than nine months, has won numerous awards. But the director reported being told from the start that due to the pressure to complete the project within one academic year, she and other community members "wouldn't really have much input" in the development of the design once under way. I won't diminish the important contribution of this project, but from an educational and social perspective, this kind of one-way relationship from donors of design services to recipients of aid -which I call the 'Design Assistance' model -leaves much to be desired. Unfortunately though, many factors inherent to the professional and academic systems of reward and advancement weigh strongly against the potential rewards of more open and truly collaborative partnerships.

In the design professions, accolades and honors are typically assessed based on the formal and functional qualities of the design objects that are produced. Rarely, if ever, are projects recognized for the more intangible effects on the public good, or of the quality of the design process itself. Difficulties in gathering, quantifying and assessing data on these intangibles is compounded by the fact that many of these benefits might not become apparent for years after the initial design collaboration. In academic settings community-based projects are often undertaken by younger faculty members, but the pressures of tenure review can often limit the scope and effectiveness of their efforts. Beyond the enormous time commitments necessary and the well-documented difficulties of determining how to 'count' this work within the triad of research teaching and service, issues of 'ownership' also become problematic since the academic value system continues to reward 'sole authorship' much more highly than it does collaborative work.

Given these conditions and existing biases, it should be no surprise that many community-based design projects struggle to truly engage their clients as real collaborators, and that they rarely include adequate post-project analysis or reflection. Following the traditional model of professional design services, a more-or-less one way relationship of Design Assistance is often rendered, pro-bono, and with the best intentions, but still lacking the true depth and reciprocity that might better serve the larger public good. In formulating a model that I am calling 'Design Engagement,' many questions arise that have strong implications for both the design professions and their academic counterparts. Foremost among these questions is: how might a viable Design Engagement project work?

\section{DESIGN ENGAGEMENT}

Most architects work within well established professional norms of client relationships and design processes. In architecture, the typical design process is codified in the AIA's recommended template for contractual services. Starting with pre-design, the process proceeds to schematic design, design development, construction documents, and construction observation. Although the pre-design and schematic phases are intended to include research into client and community needs, these do not represent anything near the bulk of the designers work or time commitment, which is reserved for defining the more technical aspects of the object to be built. And while the process is intended to include opportunities for client input and feedback at every stage, there are contractual safeguards that insure these do not become impediments to the forward trajectory of the project. Furthermore, this rubric has never formally included any sort of post-occupancy feedback or evaluation. And while some of the most conscientious firms and practitioners do return to learn about the outcomes of their hypotheses, most do not. It is clear that this approach to the design process might work for corporate or other paying clients, but simply following the same path, but on a pro bono basis, does not adequately address the demands of a community-based project that seeks to truly address the public good. The design process itself needs to be re-designed.

In order to move from Design Assistance toward Design Engagement, more inclusive and collaborative sets of design activities need to be imagined, tested, evaluated and disseminated. In this scenario, the design schools will continue to play a vital role, but only as long as they are willing to place 
value on the design process itself, not just on the objects that are but one manifestation of its outcome. In the limited scope of this essay, I will not presume to offer a singular definition of a successful Design Engagement approach. Rather, I will propose a set of four principles and practices that seem important, and compare these with long-standing 'bestpractice' educational programs that embody at least some of them.

In my experience running several community-collaborative design-build projects and evaluating numerous others, among the most important components of a Design Engagement process are:

1) Acknowledging mutual value and values before commencing any work

2) Re-defining problems and opportunities to arrive at meaningful scopes of work

3) Mutually defining risk, success and failure -which is crucial to avoiding later misunderstanding; and

4) Getting serious about feedback, evaluation and reflection

Most of these principles really focus on the central necessity for creating and renewing more effective practices of communication. While these four approaches to improving collaborative design are not exhaustive, they might help to establish a starting point for imagining new practices that challenge the status quo of one-way Design Assistance models. For community-engaged design to serve the public good in more productive ways, our design processes themselves must be re-considered, and key to this is the last tenet: getting real about feedback. Unless we can pro actively reflect on both our successes and our shortcomings, true collaborative design engagement cannot grow and succeed.

The following brief selection of university programs exemplify important approaches that have contributed to the formulation of engaged practices of design in the public interest. Many programs have followed the model of one of the earliest and most long-standing examples, The Yale Building Project. Founded in 1967 this program strives to build one affordable home for needy residents of New Haven each year. $^{12}$ While embodying a Design Assistance approach, the Yale commitment to working within the same neighborhoods and learning from project to project make it exemplary. Although not quite as long standing, the Rural Studio founded by Sam Mockbee at Auburn University, is by far the most well-known and influential of the design-build programs. ${ }^{13}$ Similarly committed to one region (rural rather than urban) the range of different project types and commitment to long-term engagement are among the hallmarks of this program. One of their innovations is the "20K House" initiative that has advanced research and delivery of ultra-low cost homes in the rural south. ${ }^{14} \mathrm{~A}$ third noteworthy example is the Studio 804 program at the University of Kansas that has successfully competed with for-profit design firms nationally, winning the coveted Architecture Magazine's Home of the Year award for it's Prefab 3 project in 2006. ${ }^{15}$ In recent years Studio 804 has stopped working directly with community partners and instead acts as sole developer and builder of low-cost housing. They have also completed noteworthy non-residential projects like the Marvin Forum addition to Marvin Hall at the University of Kansas (Figure 4), their seventh LEED Platinum building to date. ${ }^{16}$ This approach moves Studio 804 further away from collaboration and instead aims more at an experimental form of professionalized designbuild practice.

While primarily examples of Design Assistance methodologies, each of these award-winning programs takes a unique approach to project type, scale, time frame, and practice models. There are exemplary of widespread trends in designbuild education, but they vary widely in their approaches to and degree of community engagement and contribution to the public good.

Another, and quite different approach of note is the Detroit Collaborative Design Center. Focusing more on collaborative action in the urban environment than on the construction of discrete buildings, the Detroit CDC was founded in 1990 at the University of Detroit Mercy and is directed by Dan Pitera. Their mission is to "foster university and community collaborations and partnerships that create inspired and sustainable neighborhoods and spaces for all people." 17 While there are many university-based CDCs, the Detroit Collaborative Design Center is one of the most successful and widely acclaimed efforts. It differs from design-build programs in its wider range of project types and collaborations. Rather than focusing primarily on the design and construction of one-off structures, they work at multiple scales and with greater breadth and flexibility to address Detroit's numerous challenges. One of the hallmarks of this program is their process of collaboration with artists and designers of all kinds in order to widen the reach of community-based design well beyond the typical scope of architectural practice. A recent example is the "Live6 Alliance" project. The DCDC website describes the project this way: "Through design and community engagement support, DCDC assisted Live6 in its initiatives by helping coordinate and execute community events that build bridges between residents, institutions, and businesses." 18 (Figure 5) The Detroit CDC is a great example of a Design Engagement approach. 


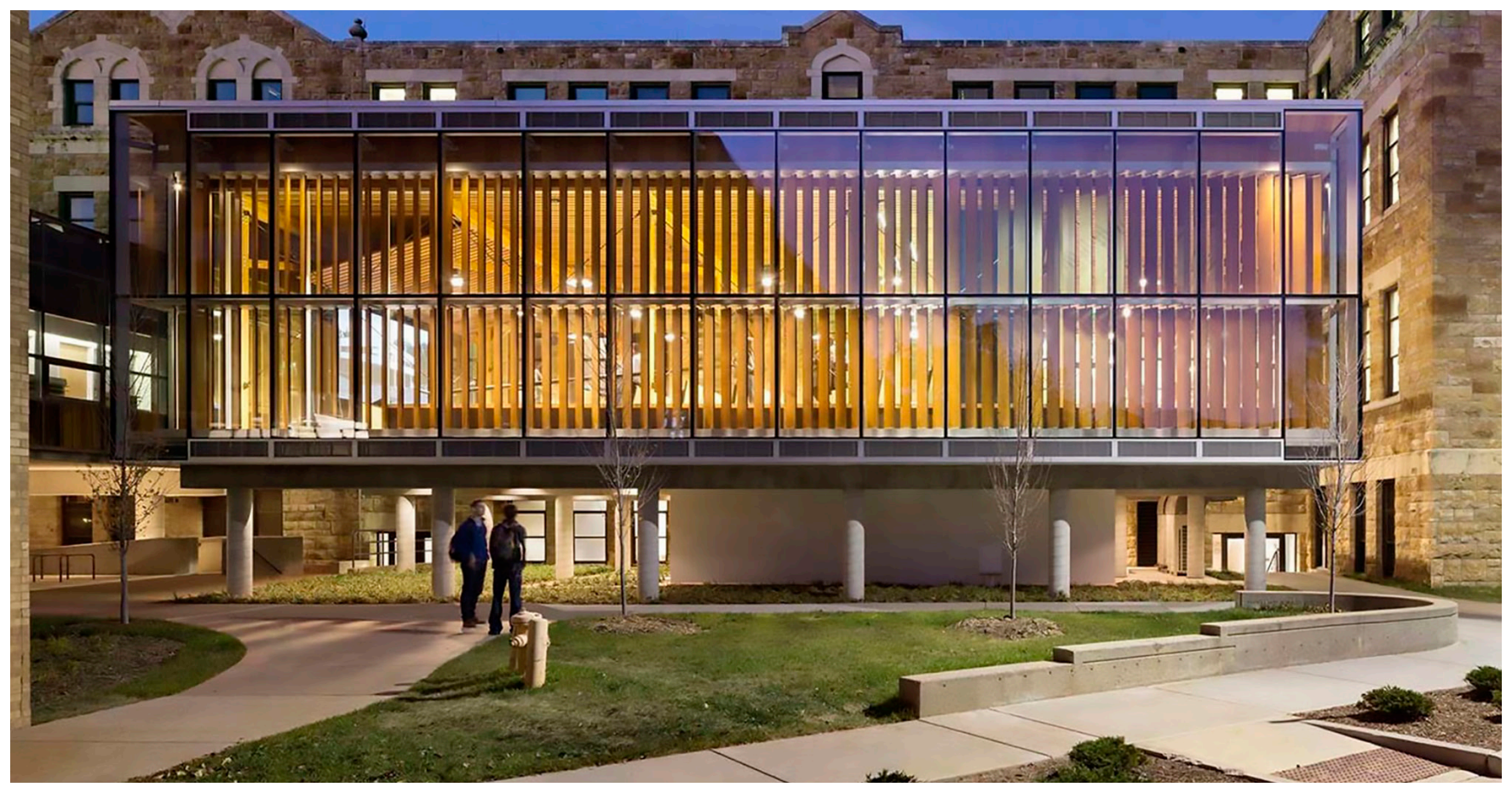

Figure 4: “The Forum” Addition to Marvin Hall, University of Kansas by Studio 804, 2014

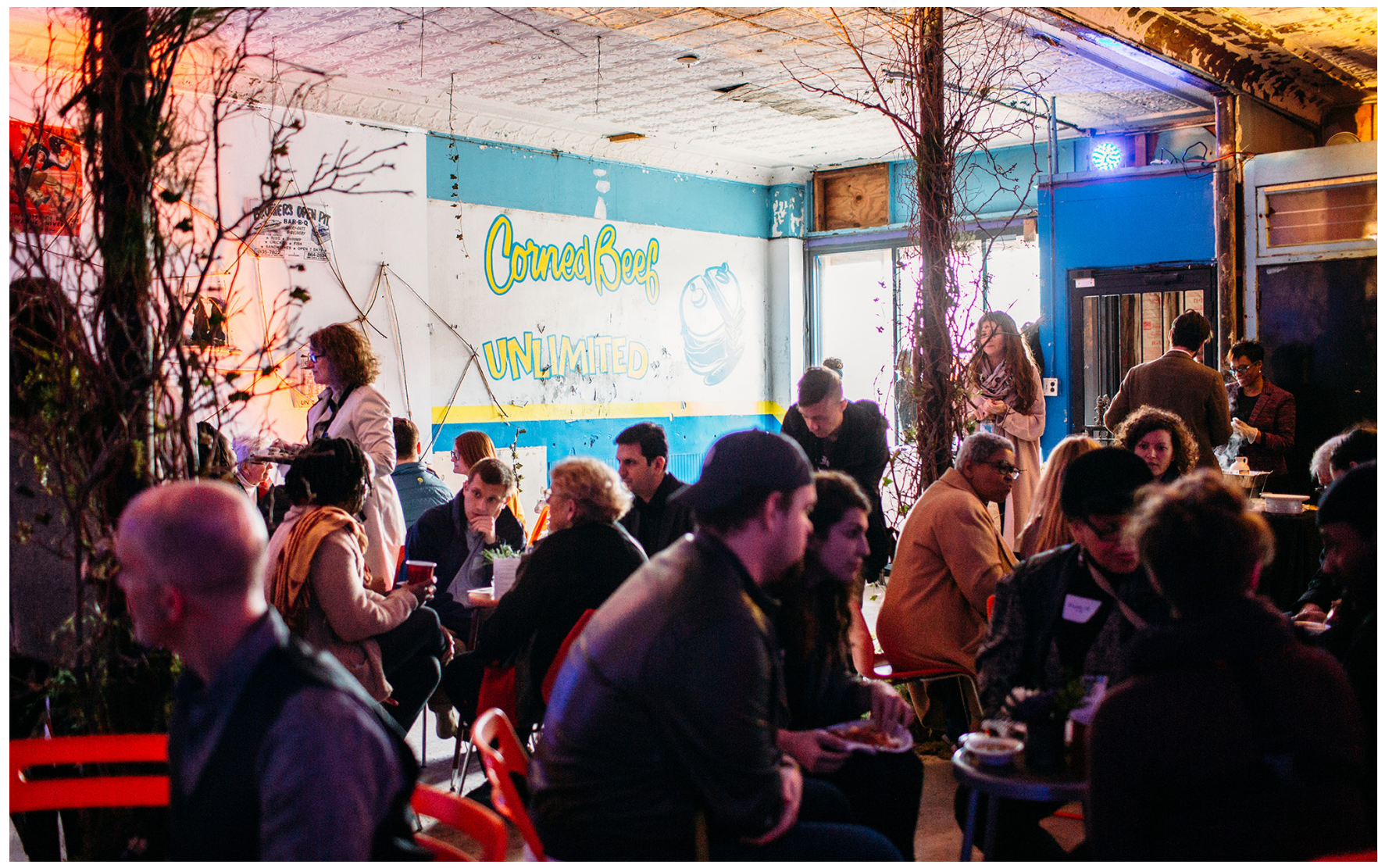

Figure 5: The Detroit Collaborative Design Center's ongoing "Live6 Alliance” project. 


\section{PROFESSIONAL TRANSFORMATION / SOCIAL TRANSFORMATION}

In Robert Goodman's 1972 book After the Planners, ${ }^{19}$ he presents a blistering critique of the kind of post-war urban planning that resulted in socially destructive urban renewal and highway construction, often through disadvantaged urban neighborhoods. Former Harvard Professor George Baird describes Goodman's contributions to architecture and politics:

...for Goodman the entire formal apparatus of architecture had become at best irrelevant, and at worst oppressive. He concluded by calling for architects to reject what he saw as their traditional roles: "Instead of remaining the 'outside expert' trying to resolve the conflicting needs of the low-middle-high income metropolis, or simply 'helping the poor,' we can become participants in our own community's search for new family structures or other changing patterns of association, and participants in the process of creating physical settings which would foster these ways of life-in effect, we become a part of rather than an expert for, cultural change. ${ }^{20}$

Baird goes on to describe this approach - in his words a new "style of action" - as a form of "guerilla architecture." 21 Perhaps this style of action might serve as a new model for the professional activities of architects, planners, and designers of all kinds who strive for greater social relevance.

Long-standing concepts of professional status, privilege and social responsibility, while useful in maintaining minimum standards of public safety, do not adequately serve the intense need in our societies for greater inclusion and participation in working toward social justice. While the NAAB requirements retreat to less explicit, more professionalized stances regarding public service, university based programs proliferate. Many follow professional norms and contribute valuable Design Assistance to communities and clients. But despite a few notable efforts, there still aren't many university programs that challenge professional models and really aim to be more truly collaborative Design Engagement initiatives. We need to explore, document, and share fresh approaches in the pursuit of the greater social good, both in academia and in professional practice. If design continues to be construed narrowly as primarily the creation of objects, no matter how functional, sustainable or beautiful, then the status quo of misaligned priorities and cultural misunderstanding might likely be perpetuated. If, however, architects engage in a critical re-working of the design process itself, by exploring more effective ways to work collaboratively and embed their work within the richness of their communities, then the greater public good might be better served.
This paper was initially developed as a study and presented at Imagining America in 2008. It is here updated and re-focused to emphasize the ongoing challenges still in play for the architectural profession and design education.

\section{ENDNOTES}

1 http://info.aia.org/aiarchitect/thisweek06/1215/1215n_whitney.cfm, accessed 08/12/09.

2 http://dictionary.oed.com, accessed 09/1/17.

3 "AlA Code of Ethics and Professional Conduct, 2017", http://aiad8.prod.acquiasites.com/sites/default/files/2017-08/2017\%20Code\%20Update.pdf, accessed 09/1/17.

4 Ibid., p.2.

5 "INSTITUTE GUIDELINES to Assist AIA Members, Firms and Components in Undertaking Pro Bono Service Activities," http://www.aia.org/aiaucmp/groups/ aia_members_only/documents/pdf/aiab043436.pdf, accessed 08/12/09, (Washington, DC: the American Institute of Architects, 2008) p.6.

6 Ibid., p.1.

Ibid., p.2

8 http://www.naab.org/accreditation/2004_Conditions.aspx, accessed 08/12/09.

9 http://www.naab.org/wp-content/uploads/2009-Procedures-for-Accreditation.pdf, accessed 09/1/17.

10 http://www.naab.org/wp-content/uploads/01_Final-Approved-2014-NAABConditions-for-Accreditation.pdf, accessed 09/1/17.

11 Boyer and Mitgang, "Building Community: A New Future for Architecture Education and Practice", (Princeton: Carnegie Foundation for the Advancement of Teaching, 1996), p. 9.

12 Hayes, Richard W. The Yale Building Project: The First 40 Years, (New Haven: Yale School of Architecture, 2007).

13 Andrea Oppenheimer Dean and Timothy Hursley, Rural Studio: Samuel Mockbee and an Architecture of Decency. (New York: Princeton Architectural Press, 2002); and Andrea Oppenheimer Dean and Timothy Hursley, Proceed and Be Bold: Rural Studio After Samuel Mockbee. (New York: Princeton Architectural Press, 2005).

14 http://www.ruralstudio.org/initiatives/20k-house, accessed 09/1/17.

15 http://studio804.com/2006-modular-3.html, accessed 09/1/17.

$16 \mathrm{http} / /$ studio804.com/2014-the-forum-at-marvin-hall.html, accessed 09/1/17.

17 http://www.dcdc-udm.org/about/, accessed 09/1/17

18 http://www.dcdc-udm.org/projects/catalysts/live6/, accessed 09/1/17.

19 Robert Goodman, After the Planners (New York: Simon and Schuster, 1972).

20 George Baird, The Space of Appearance (MIT Press, 2003) p. 264.

21 Ibid. 